\title{
Evaluation of Angle of Excitation for Torsion by Using Irregularities in R.C.C Frame
}

\author{
Danish Ali ${ }^{1}$, Mangulkar Madhuri $\mathrm{N}^{2}$

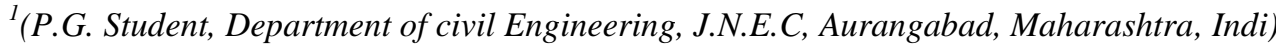 \\ ${ }^{2}$ (Assistant Professor, Department of civil Engineering, J.N.E.C, Aurangabad, Maharashtra, India)
}

\begin{abstract}
Torsional behaviors of asymmetric and irregular R.C.C structures are one of the most frequent sources of structural failure during strong ground motions. In this paper $G+9$ stories irregular shape building considered with mass, stiffness irregularity. For the evaluation of critical angle of seismic incidence for torsion by using dynamic analysis response spectrum method in STAAD PRO as per I.S 1893-2002. Set values from 0 to 90 degree with increment of 10 degree interval have been used for angle of excitation. Building column divided into three main categories including corner, side and middle column. The angle at which maximum torsional moment is obtain that is considered as a critical angle and results are compared in terms of axial force, bending moment and shear force for column.
\end{abstract}

Keywords:Mass and Stiffness Irregularity, I.S 1893-2002, Torsion, Angle of Excitation, Column Forces.

\section{INTRODUCTION}

Because of the nature of earthquake, a dual design philosophy has been adopted for the design of building in earthquake prone regions. The buildings which do not fulfill the requirements of seismic design, may suffer extensive damage or collapse if shaken by a severe ground motion. The seismic evaluation reflects the seismic capacity of earthquake vulnerable buildings for the future use. It has been analyses that survey conducted on modes of failure of building structures during past severe earthquakes concluded that most vulnerable building structures are those, which are asymmetric in nature. Asymmetric-plan buildings, namely buildings with in-plan asymmetric mass and strength distributions, are systems characterized by a coupled torsional-translational seismic response. Asymmetric building structures are almost unavoidable in modern construction due to various types of functional and architectural requirements. IS 1893-2002 code deal with torsion by placing restrictions on the design of buildings with irregular layouts and also through the introduction of an accidental eccentricity that must be considered in design. The lateral-torsional coupling due to eccentricity between center of mass $(\mathrm{CM})$ and center of rigidity $(\mathrm{CR})$ in asymmetric building structures generates torsional vibration even under purely translational ground shaking. During seismic shaking of the structural systems, inertia force acts through the center of mass while the resistive force acts through the center of rigidity as shown in figure No.1.

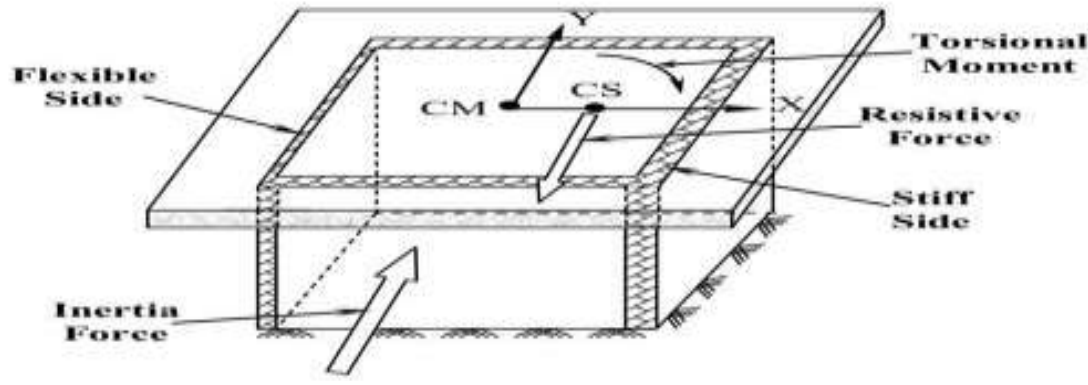

Figure No.1:- Generation of torsional moment in asymmetric structures during seismic excitation.

Although irregular buildings are preferred due to their functional and aesthetic considerations torsion is generally occur due to irregularities in frame structure following are the different types of irregularities as shown in figure No. 2 The framed structure is one of the most significant modern developments in high rise structural form. The lateral resistance of framed structures of different geometric plans (H-shape, T-shape, Irregular shape etc.) is provided by very stiff moment resisting frames. The gravity loading is shared between interior columns. This structural form offers an efficient, easily constructed structure appropriate for buildings less than $\mathbf{4 0}$ meters. Design eccentricities include a multiplier on the static eccentricity to account for possible dynamic amplification of the torsion. Also, the design eccentricities often include an allowance for accidental torsion that is supposed to be induced by the rotational component of ground motion, by possible deviation of the ECR(elastic center of resistance) and center of mass (CM) from their calculated positions or by unfavorable distribution of live loads. The design eccentricity formulae given in B.I.S 1893-2002 code can be written in the following form. 


$$
\text { edi }=\alpha e+\beta b
$$

or

edi $=\alpha e-\beta b$

-Eq.1

The torsion design provisions of Indian Standard (IS-1893:2002 (Part1)) specify the use of design eccentricity expressions Eq. 1 with $\alpha=1.5, \beta=0.05$ and $\gamma=1$.Eqs. 1 result four possible design center of mass (DCM) locations in each floor of the building.

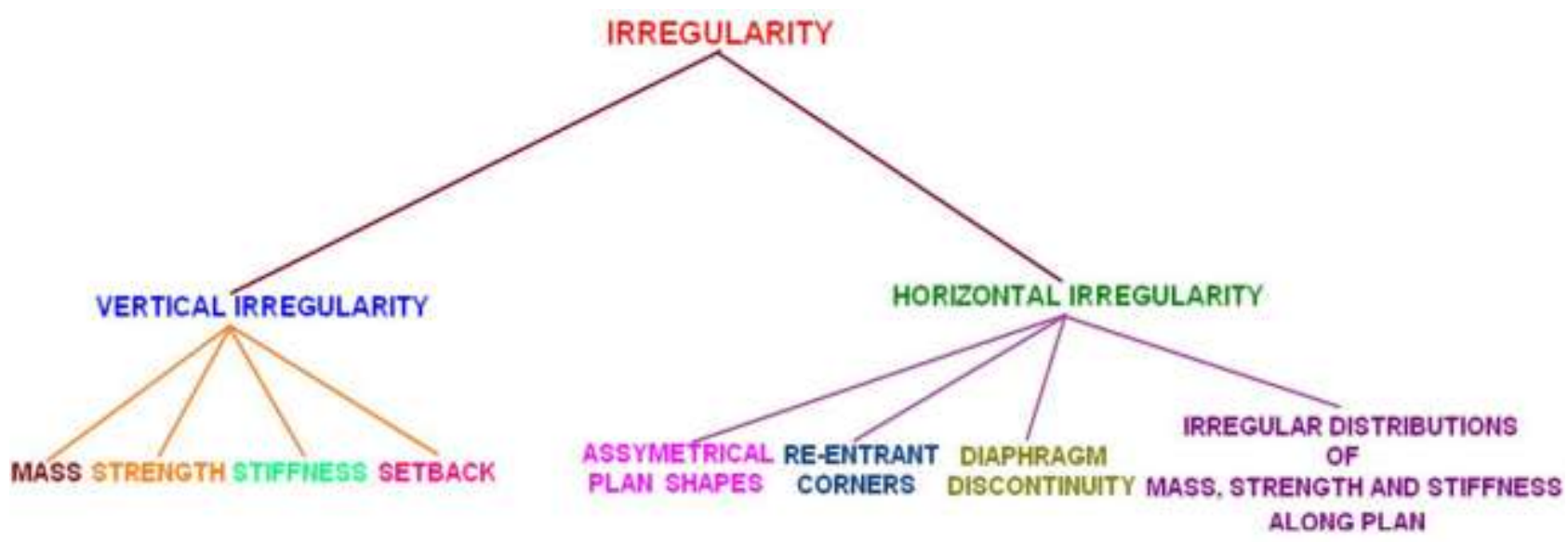

Figure No.2: Classification of different types of irregularities.

\subsection{Indian Standard 1893-2002 (part-1) Provision for Torsion}

The torsion design provisions of Indian Standard (IS-1893:2002(Part1)) specify the use of design eccentricity expressions Eq. 1 with $\alpha=1.5$ and $\beta=0.05$. IS 1893:2002 (Part1) does not permit any reduction of lateral strength resulting from negative shear due to the effect of eccentricity. Indian Standard also recommended that dynamic analysis is required to perform for an irregular framed building higher than $12 \mathrm{~m}$ in Zone IV and Zone V (PGA $=0.24 \mathrm{~g}$ and $0.36 \mathrm{~g}$ respectively) and $40 \mathrm{~m}$ in Zone II and Zone III ( $\mathrm{PGA}=0.10 \mathrm{~g}$ and $0.16 \mathrm{~g}$ respectively). Building with $\delta \mathrm{max} / \delta \mathrm{avg} \geq 1.2$ are defined as torsional irregular in IS $1893: 2002$. Where $\delta \max$ is the maximum displacement of the floor produced by the equivalent static earthquake forces, and $\delta$ avg $=(\delta 1+\delta 2) / 2$ is the average of the displacements of the extreme points of the structure. $\delta \mathrm{max}=\delta 2$ and $\delta$ avg (Fig. 1.2) should be computed with the design eccentricity. Indian standard 1893-2002 code provision for mass irregularity shall be considered to exist where the seismic weight of any stored is more than 200 percent of that of its adjacent story. The irregularity need not be considered in case of roofs and mass irregularity as shown in figure 1.3 while the stiffness irregularity as shown in figure No 3.

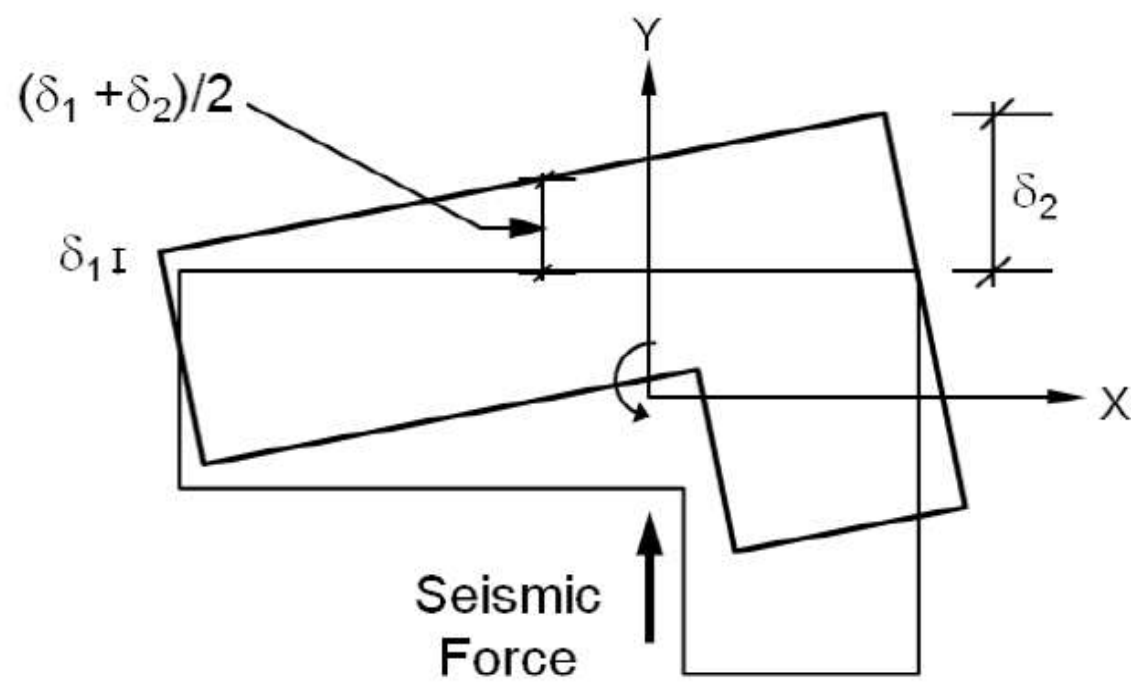

Figure No 3: Figure explaining $\delta \mathrm{max}$ and $\delta$ avg in asymmetric building.

For the mass irregular building and stiffness irregular building As per BIS 1893-2002 code provision as shown in figure No 4 and figure No 5 respectively. 

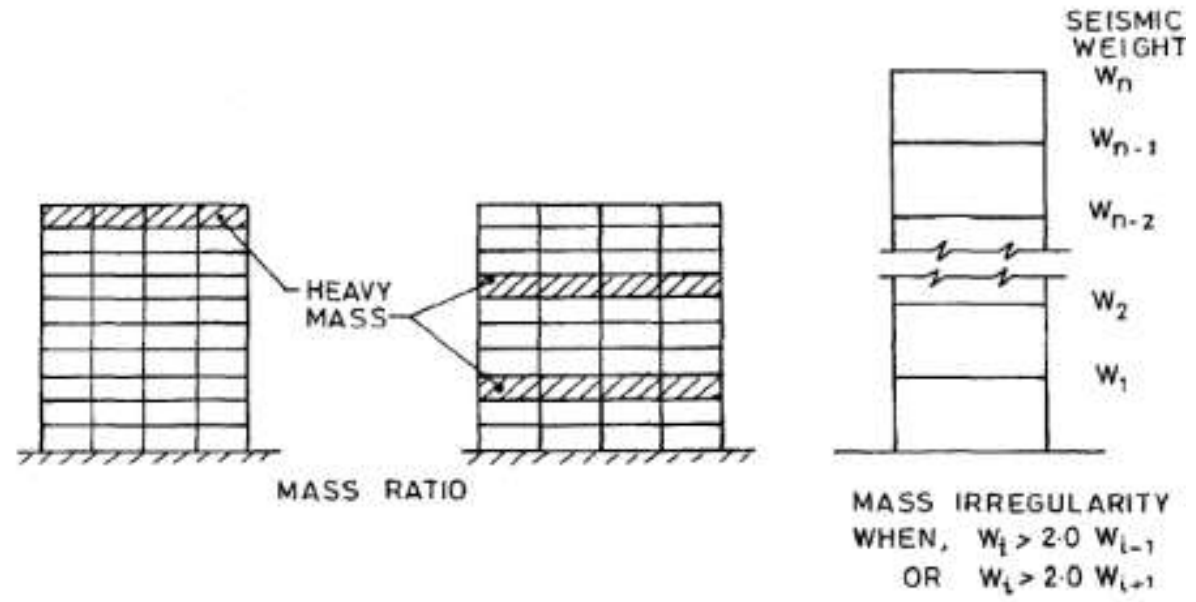

Figure No.4: Mass irregularity as per BIS 1893-2002 code provision

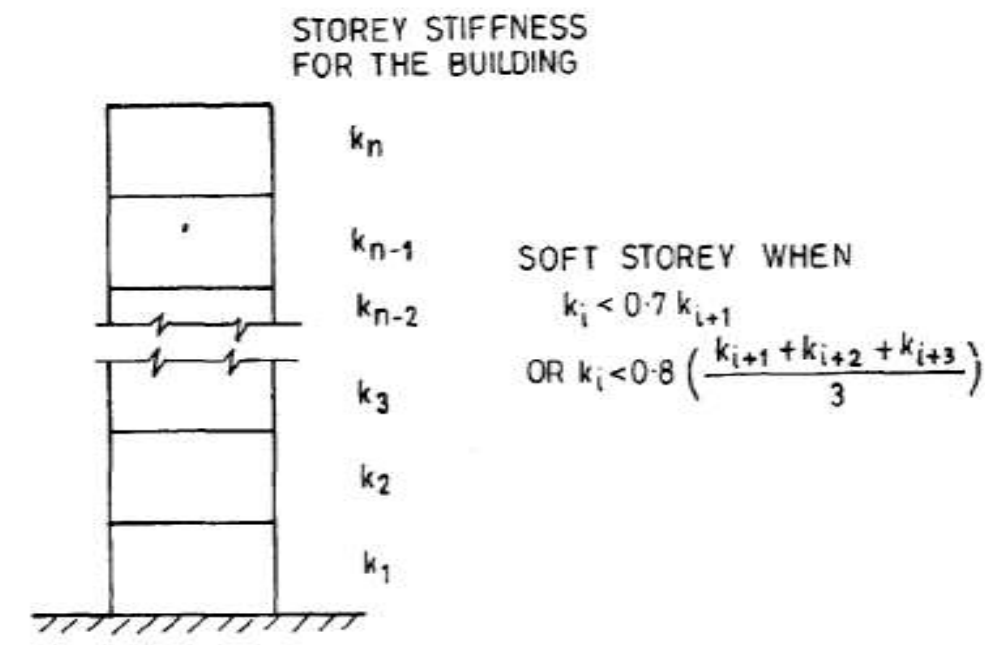

Figure No 5: Stiffness irregularity as per BIS 1893-2002 code provision

II.

FRAME STRUCTURE DETAILS

In this present study G+9 irregular building of R.C.C frame structure with mass, stiffness irregularity and combine both mass and stiffness irregularity is taken and dynamic analysis by using response spectrum method with consideration of accidental eccentricity with the help of STAAD PRO software. The position of different type of columns i.e. corner, side, middle C1, C2, C3 respectively for model of irregular building of irregular shape structure as shown in figure No.6 and The modal specification of the irregular frame structure as shown in table No.1.

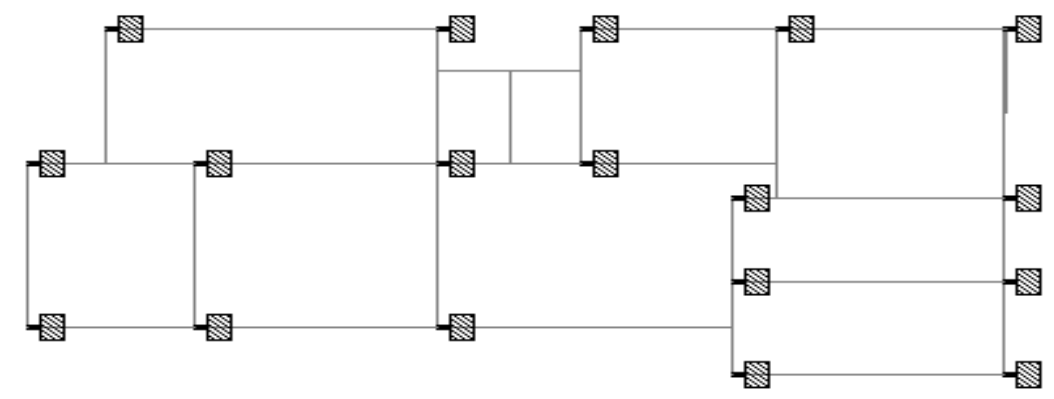

Figure No.6: Figure shows model of irregular building

Table No.1: Specification of model

\begin{tabular}{|c|c|c|}
\hline $\begin{array}{c}\text { Sr. } \\
\text { No. }\end{array}$ & \multicolumn{1}{|c|}{ Type Of Structure } & G+9 Moment Resisting Frame Structure \\
\hline $\mathbf{1}$ & $\mathbf{2}$ & $\mathbf{3}$ \\
\hline 1. & General Floor To Floor Height & $3.1 \mathrm{~m}$ \\
\hline
\end{tabular}




\begin{tabular}{|l|l|l|}
\hline 2. & Stiffness Irregularity & $4.5 \mathrm{~m} \mathrm{At} 2^{\text {nd }}, 4^{\text {th }}, 6^{\text {th }}$, And $8^{\text {th }}$ Floor \\
\hline 3. & Mass Irregularity (External Wall) & $40 \mathrm{kN} / \mathrm{Sq}-\mathrm{m} \mathrm{At} 2^{\text {nd }}, 4^{\text {th }}, 6^{\text {th }}$, And $8^{\text {th }}$ Floor \\
\hline 4. & Mass Irregularity (Internal Wall) & $25 \mathrm{kN} / \mathrm{Sq}-\mathrm{m} \mathrm{At} 2^{\text {nd }}, 4^{\text {th }}, 6^{\text {th }}$, And $8^{\text {th }}$ Floor \\
\hline 5. & Live Load & $3 \mathrm{KN} / \mathrm{Sq}-\mathrm{m}$ \\
\hline 6. & Dead Load (External Wall) & $15 \mathrm{kN} / \mathrm{Sq}-\mathrm{m}$ \\
\hline 7. & Dead Load (Internal Wall) & $10 \mathrm{kN} / \mathrm{Sq}-\mathrm{m}$ \\
\hline 8. & Seismic Zone & V, As Per Is 1893-2002, Z=0.36 \\
\hline 9. & Type Soil & Medium Soil = li \\
\hline 10 & Corner Column (C1) & $230 \times 300$ \\
\hline 11. & Side Column (C2) & $230 \times 450$ \\
\hline 12. & Middle Column (C3) & $300 \times 550$ \\
\hline
\end{tabular}

Model shows the geometry in a vertical axis for mass irregular shape structure and stiffness irregular shape structure as shown in figure: 7 and figure: 8 .

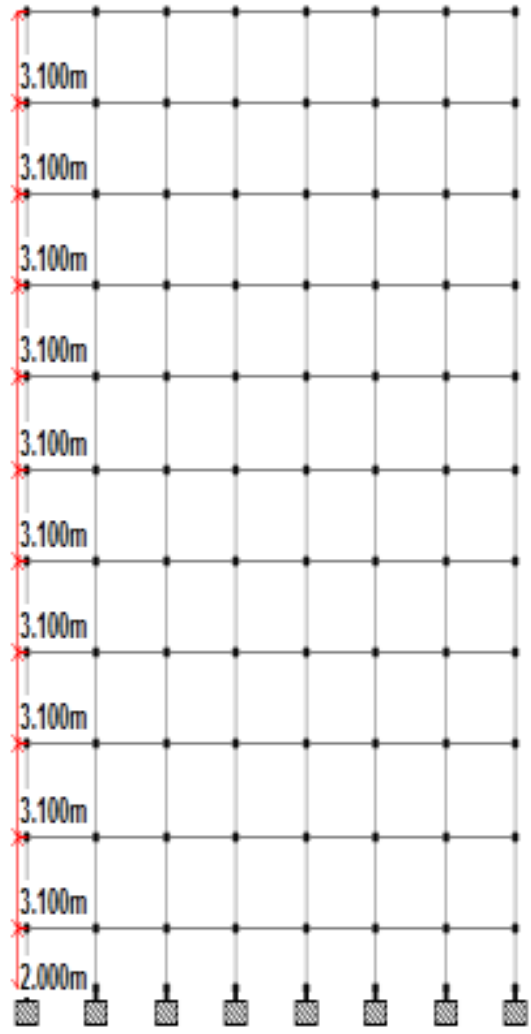

Figure No.7: Front view of mass irregular shape Structure.

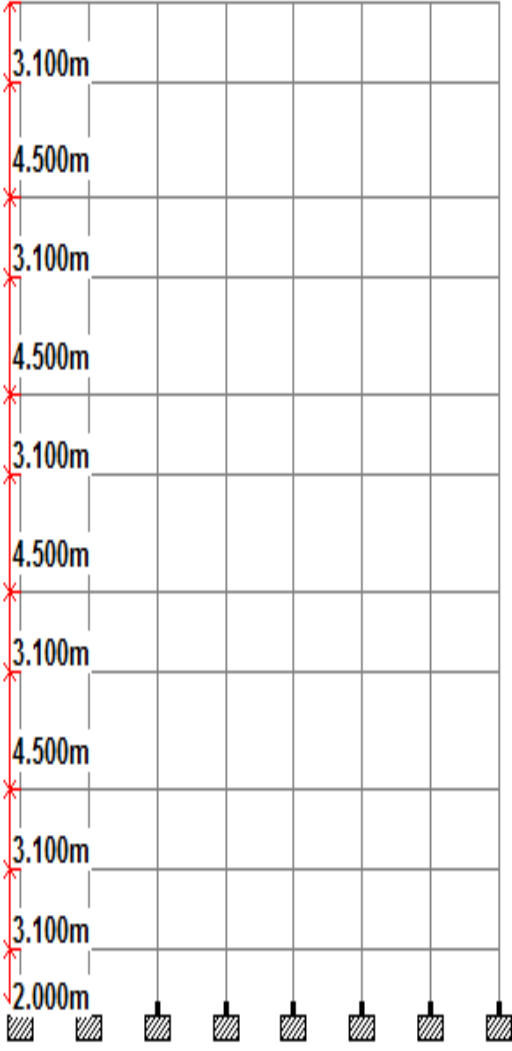

Figure No.8: Front view of stiffness irregular shape Structure.

III. METHODOLOGY

The present work deals with dynamic analysis response spectrum method considering accidental eccentricity. response spectrum method for $\mathrm{x}$ and $\mathrm{z}$ direction so in order to apply the forces at different angle structure has to be rotate with incident angle from 0 to 90 degree with increment of 10 degree interval further to find out the accurate angle the interval of one degree is used. The angle at which maximum torsional moment is obtain that is considered as a critical angle and the columns have been divided in three categories including corner, side and middle.

\section{EXPERIMENTAL RESULTS}

Table No: 2 represent the percentage variation of stiffness irregular structure in terms of axial force, shear force and bending moment at critical angle where we get maximum torsional moment.

Table No.2: Results of stiffness irregular structure

\begin{tabular}{|c|c|c|c|c|c|}
\hline $\begin{array}{l}\text { Sr. } \\
\text { No. }\end{array}$ & $\begin{array}{l}\text { Col } \\
\text { No. }\end{array}$ & $\begin{array}{l}\text { Critical } \\
\text { Angle }\end{array}$ & $\begin{array}{c}\text { Moment and forces } \\
\text { at } 0 \text { degree }\end{array}$ & $\begin{array}{l}\text { Moment and forces at } \\
\text { critical angle }\end{array}$ & $\begin{array}{l}\text { Percentage variation } \\
\text { in moment and forces }\end{array}$ \\
\hline
\end{tabular}




\begin{tabular}{|c|c|c|c|c|c|c|c|c|c|c|c|}
\hline & & $($ degree $)$ & $\begin{array}{c}\mathrm{Fy} \\
(\mathrm{KN})\end{array}$ & $\begin{array}{c}\mathrm{My} \\
(\mathrm{KN}-\mathrm{M})\end{array}$ & $\begin{array}{c}\mathrm{Mz} \\
(\mathrm{KN}-\mathrm{M})\end{array}$ & $\begin{array}{c}\mathrm{Fy} \\
(\mathrm{KN})\end{array}$ & $\begin{array}{c}\mathrm{My} \\
(\mathrm{KN}-\mathrm{M})\end{array}$ & $\begin{array}{c}\mathrm{Mz} \\
(\mathrm{KN}-\mathrm{M})\end{array}$ & $\begin{array}{c}\mathrm{Fy} \\
(\%)\end{array}$ & $\begin{array}{c}\mathrm{My} \\
(\%)\end{array}$ & $\begin{array}{c}\mathrm{Mz} \\
(\%)\end{array}$ \\
\hline 1. & $\mathrm{C} 1$ & 89 & 75.02 & 127.25 & 117.9 & 75.24 & 123.59 & 118.21 & 0.29 & 2.96 & 0.26 \\
\hline 2. & $\mathrm{C} 2$ & 27 & 105.85 & 220.33 & 243.97 & 99.72 & 201.99 & 228.05 & 6.14 & 9.079 & 6.98 \\
\hline 3. & $\mathrm{C} 3$ & 87 & 191.79 & 428.91 & 451 & 191.93 & 416.95 & 451.49 & 0.072 & 2.86 & 0.11 \\
\hline
\end{tabular}

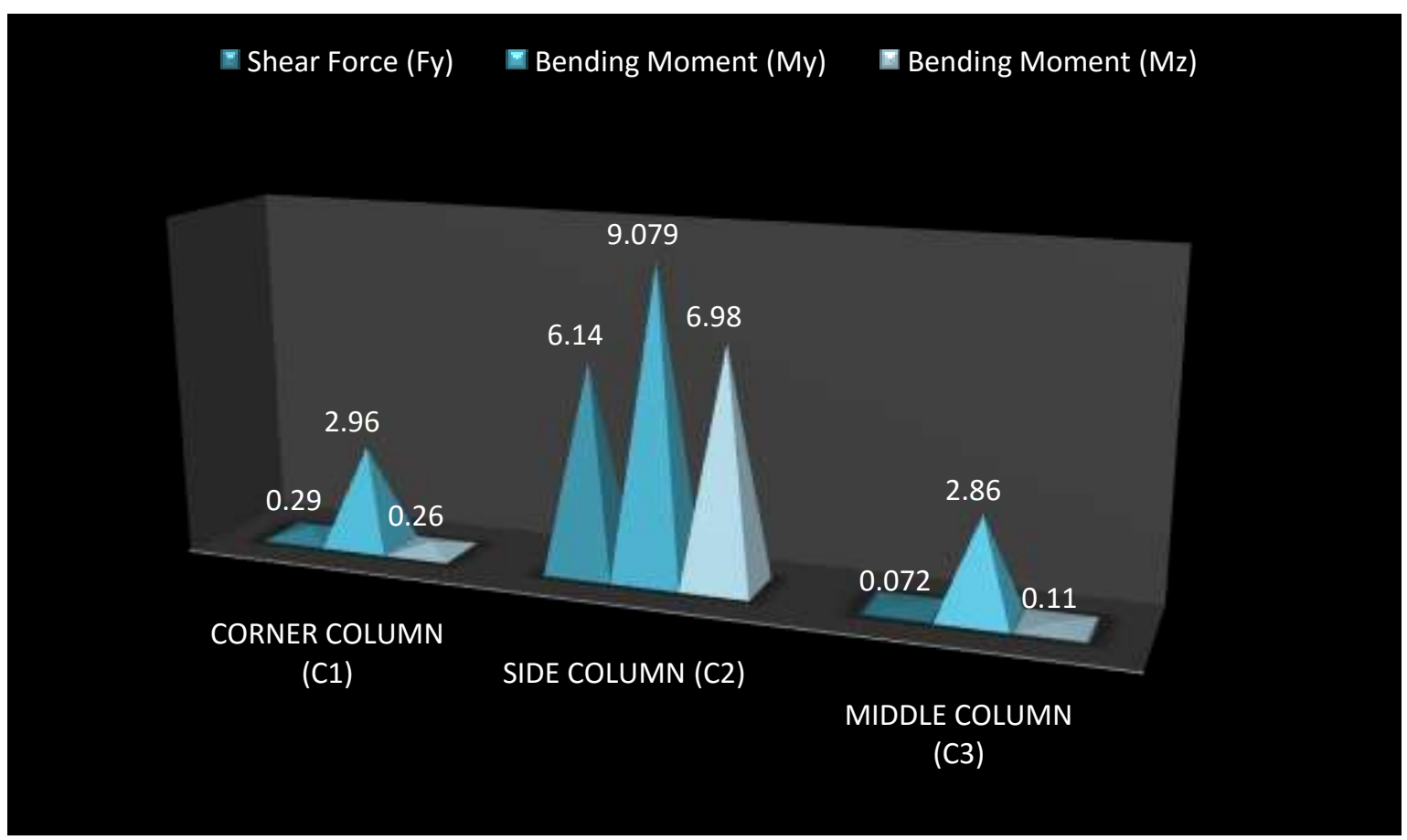

Figure No.9: Shows percentage variation in shear force and bending moment of stiffness irregular building.

It is seen from Table No. 2 and figure No.9 the maximum percentage variation in shear force for corner column $0.29 \%$ for side column $6.14 \%$ and for middle column $0.072 \%$.percentage variation in bending moment (My) between corner and side column is $6.119 \%$ and percentage variation in side and middle column is $6.219 \%$. If we see the results in table maximum percentage variation occur in side column as well as side column also having different critical angle for maximum torsional moment as compare to corner and middle column. It shows that side column in stiffness irregular structure more affected as compare to corner and middle column.

Table No: 3 represent the percentage variation of mass irregular structure in terms of axial force, shear force and bending moment at critical angle where we get maximum torsional moment.

Table No.3: Results of mass irregular structure

\begin{tabular}{|c|c|c|c|c|c|c|c|c|c|c|c|}
\hline \multirow{2}{*}{$\begin{array}{l}\text { Sr. } \\
\text { No. }\end{array}$} & \multirow{2}{*}{$\begin{array}{l}\text { Col } \\
\text { No. }\end{array}$} & \multirow{2}{*}{$\begin{array}{l}\text { Critical } \\
\text { Angle } \\
\text { (degree) }\end{array}$} & \multicolumn{3}{|c|}{$\begin{array}{l}\text { Moment and forces } \\
\text { at } 0 \text { degree }\end{array}$} & \multicolumn{3}{|c|}{$\begin{array}{l}\text { Moment and forces } \\
\text { at critical angle }\end{array}$} & \multicolumn{3}{|c|}{$\begin{array}{c}\text { Percentage variation in } \\
\text { moment and forces }\end{array}$} \\
\hline & & & $\begin{array}{c}\text { Fy } \\
(\mathrm{KN})\end{array}$ & $\begin{array}{c}\text { My } \\
(\mathrm{KN}-\mathrm{M})\end{array}$ & $\begin{array}{c}\mathrm{Mz} \\
(\mathrm{KN}-\mathrm{M})\end{array}$ & $\begin{array}{c}\mathrm{Fy} \\
(\mathrm{KN})\end{array}$ & $\begin{array}{c}\text { My } \\
(\mathrm{KN}-\mathrm{M})\end{array}$ & $\begin{array}{c}\mathrm{Mz} \\
(\mathrm{KN}-\mathrm{M})\end{array}$ & $\begin{array}{l}\text { Fy } \\
(\%)\end{array}$ & $\begin{array}{l}\text { My } \\
(\%)\end{array}$ & $\begin{array}{l}\mathrm{Mz} \\
(\%)\end{array}$ \\
\hline 1. & $\mathrm{C} 1$ & 90 & 98.39 & 149.66 & 200.16 & 98.39 & 145.44 & 200.16 & 00 & 2.90 & 00 \\
\hline
\end{tabular}




\begin{tabular}{|c|c|c|c|c|c|c|c|c|c|c|c|}
\hline 2. & C2 & 29 & 169.81 & 295.69 & 290.91 & 381.04 & 479.41 & 685.68 & 124 & 62.13 & 135.70 \\
\hline 3. & C3 & 90 & 289.34 & 485.12 & 558.86 & 289.34 & 472.5 & 558.86 & 00 & 2.67 & 00 \\
\hline
\end{tabular}

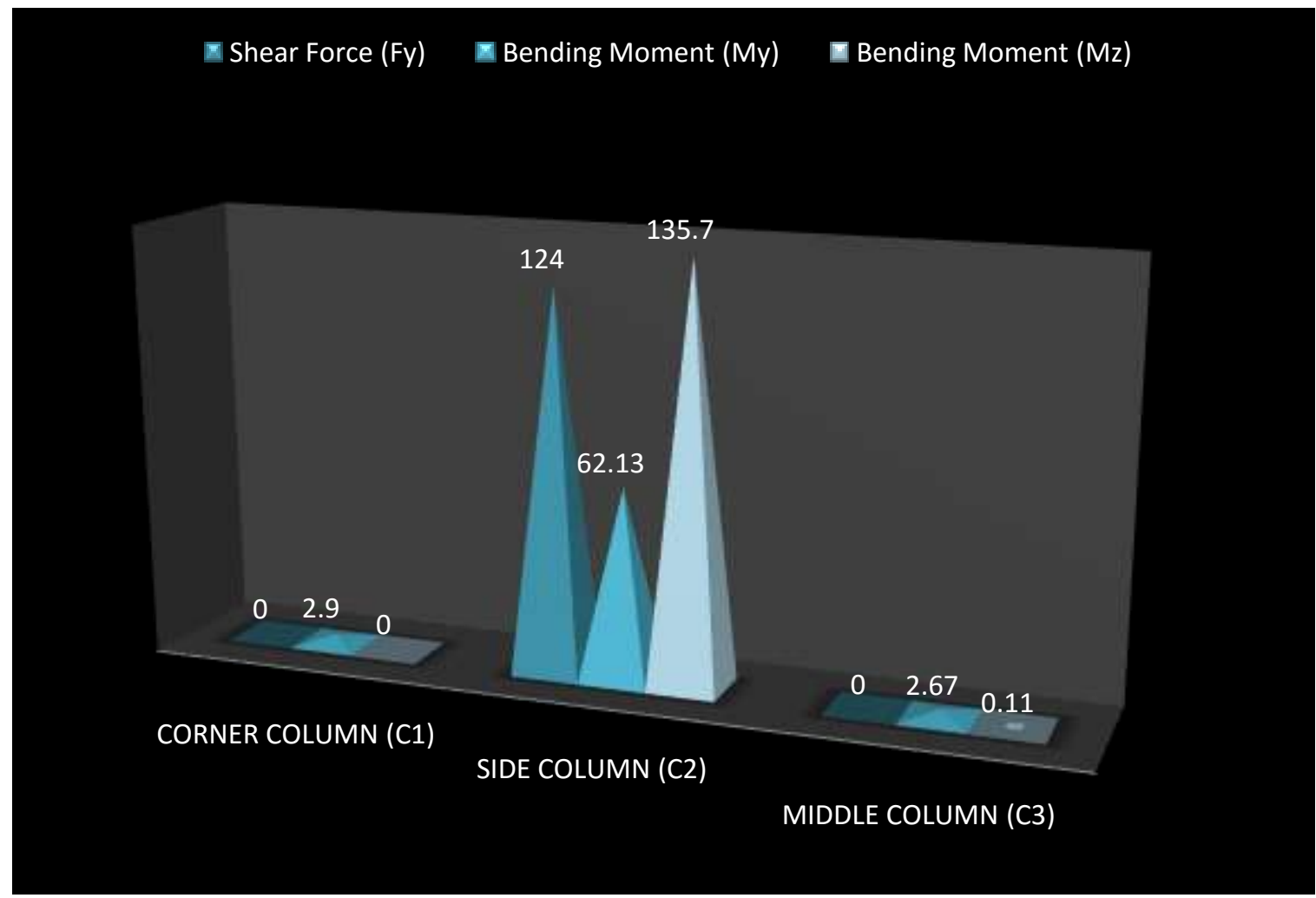

Figure No.10: Shows percentage variation in shear force and bending moment of mass irregular building.

It is seen from Table No.3 the maximum percentage variation in shear force for corner column and middle column is $00 \%$ for side column $124 \%$.percentage variation in bending moment (My) between corner and side column is $59.23 \%$ and percentage variation in side and middle column is $59.46 \%$.If we see the results in table maximum percentage variation occur in side column as well as side column also having different critical angle for maximum torsional moment as compare to corner and middle column. From the results of Table No.3 and figure No.10 it shows that the effect of torsion for corner and middle column is negligible. It shows that side column in mass irregular structure more affected as compare to corner and middle column.

Table No: 4 represent the percentage variation of combine mass and stiffness irregular structure in terms of axial force, shear force and bending moment at critical angle where we get maximum torsional moment.

Table No.4: Results of mass irregular structure

\begin{tabular}{|c|c|c|c|c|c|c|c|c|c|c|c|}
\hline \multirow{2}{*}{$\begin{array}{l}\text { Sr. } \\
\text { No. }\end{array}$} & \multirow{2}{*}{$\begin{array}{l}\text { Col } \\
\text { No. }\end{array}$} & \multirow{2}{*}{$\begin{array}{l}\text { Critical } \\
\text { Angle } \\
\text { (degree) }\end{array}$} & \multicolumn{3}{|c|}{$\begin{array}{c}\text { Moment and forces } \\
\text { at } 0 \text { degree }\end{array}$} & \multicolumn{3}{|c|}{$\begin{array}{c}\text { Moment and forces } \\
\text { at critical angle }\end{array}$} & \multicolumn{3}{|c|}{$\begin{array}{l}\text { Percentage variation } \\
\text { in moment and forces }\end{array}$} \\
\hline & & & $\begin{array}{c}\text { Fy } \\
(\mathrm{KN})\end{array}$ & $\begin{array}{c}\text { My } \\
(\mathrm{KN}-\mathrm{M})\end{array}$ & $\begin{array}{c}\mathrm{Mz} \\
(\mathrm{KN}-\mathrm{M})\end{array}$ & $\begin{array}{c}\text { Fy } \\
(\mathrm{KN})\end{array}$ & $\begin{array}{c}\text { My } \\
(\mathrm{KN}-\mathrm{M})\end{array}$ & $\begin{array}{c}\mathrm{Mz} \\
(\mathrm{KN}-\mathrm{M})\end{array}$ & $\begin{array}{l}\text { Fy } \\
(\%)\end{array}$ & $\begin{array}{l}\text { My } \\
(\%)\end{array}$ & $\begin{array}{l}\mathrm{Mz} \\
(\%)\end{array}$ \\
\hline 1. & $\mathrm{C} 1$ & 17 & 106.01 & 177.65 & 184.93 & 97.55 & 173.99 & 182.50 & 8.67 & 2.10 & 1.33 \\
\hline 2. & $\mathrm{C} 2$ & 15 & 154.90 & 310.21 & 350.49 & 149.38 & 306.30 & 344.99 & 3.69 & 1.27 & 1.59 \\
\hline 3. & $\mathrm{C} 3$ & 84 & 267.06 & 620.59 & 629.55 & 266.64 & 601.57 & 629.01 & 0.15 & 3.16 & 0.087 \\
\hline
\end{tabular}




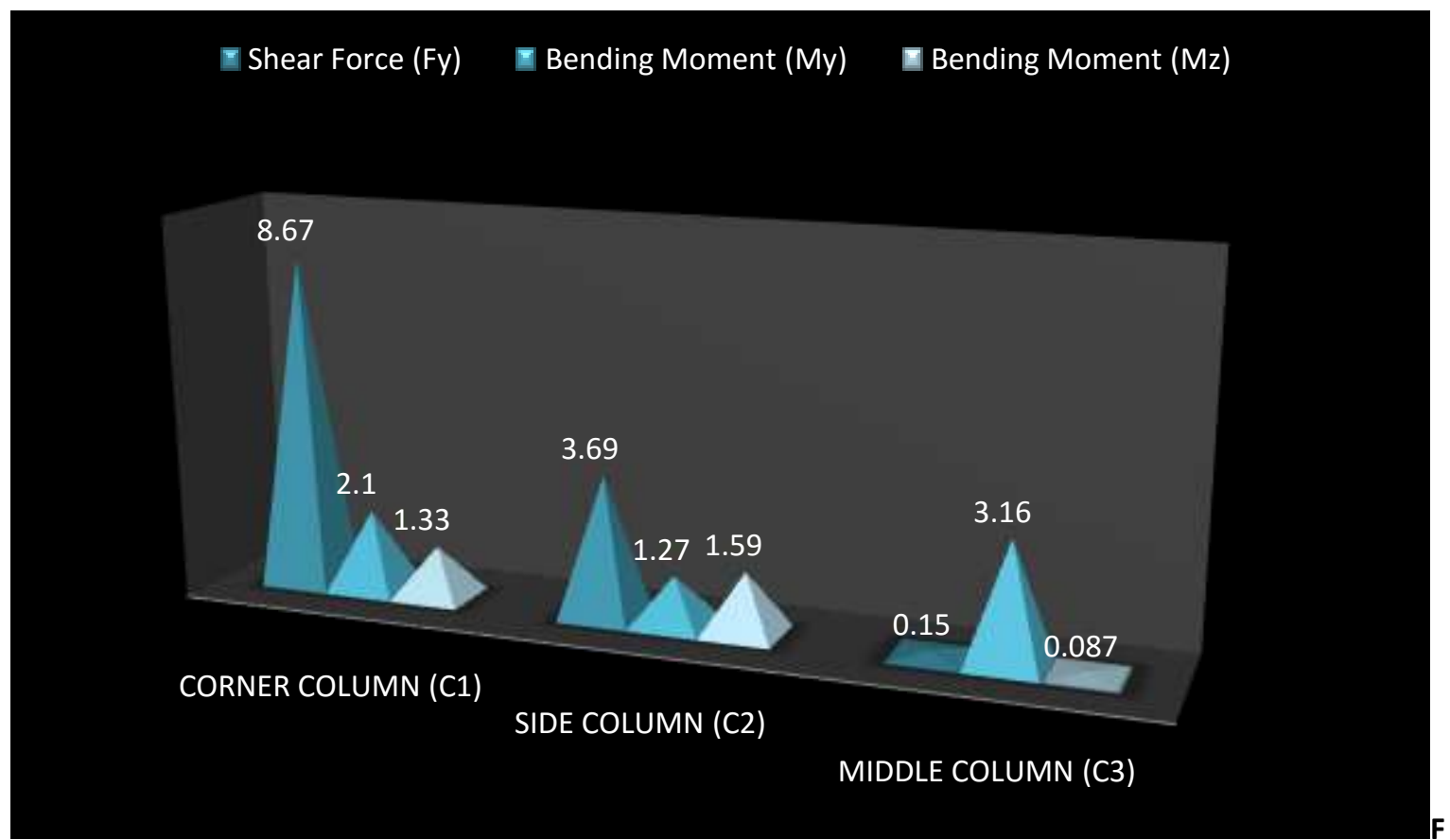

Figure No. 11: Shows percentage variation in shear force and bending moment of both mass and stiffness irregular building.

It is seen from Table No.4 the maximum percentage variation in shear force for corner column $8.67 \%$ for side column $3.69 \%$ and for middle column $0.15 \%$. Percentage variation in bending moment (My) between corner and side column is $0.83 \%$ and percentage variation in side and middle column is $1.89 \%$. If we see the results in Table No.4 and figure No.11 corner column is more affected in combine irregular structure as compare to remaining types of column in the structure.

\section{CONCLUSION}

It is concluded that the Mass irregular structure are having more percentage variation in shear force and bending moment as compare to stiffness irregular structure and combine irregular structure and the values of critical angle are not specified for all three types of irregular structure where we get the maximum torsion. Maximum percentage variation occur in side column for stiffness and mass irregular structure and in case of combine irregular structure maximum percentage variation occur at corner column. Finally it's observe that mass irregularity in the having a more affect (i.e. more than $60 \%$ variation in B.M and S.F) while considering the accidental eccentricity in the irregular structure. So that while designing each and every component of structure shall be analysed at each particular angle and consideration of torsion is necessary because it very much affected on B.M and shear force.

\section{Acknowledgements}

The authors wish to thank the management, principal, head of civil department and staff of Jawaharlal Nehru Engineering College and authorities of Dr. BabasahebAmbedkarMarathwada University and Ms. Ramchandani Jaya Rajkumar for their support

\section{REFERENCES}

[1] MahmoodHosseini and Ali Salemi, "Studying the effect of earthquake excitation angle on the internal forces of steel building's element by using nonlinear time history analysis", The $14^{\text {th }}$ world conference on earthquake engineering, October 12-17, 2008.

[2] Rajalakshmi K.R. Harinarayan S. Varughese J.A. and Girija K. "Study of torsion effect on building structures having mass and stiffness irregularities", international journal of engineering research and technology, ISSN: 2278-0181, Vol. 4 Issue 06, June2015 .

[3] Ramchandani J.R. and Mangulkar M.N. "Investigation of critical angle of seismic incidence for the analysis of RCC frames by time history method of dynamic analysis using STAAD PRO", IJMER, Vol. 6, Issue.1, January 2016.

[4] Sohel Ahmed Quadri. andMangulkarM.N."Investigation of critical angle of seismic incidence for the analysis of RCC frames", International journal of Advance in science engineering and technology, ISSN: 2321-9009, Vol. 2, Issue-3, july-2014.

[5] GeorgeGeorgoussis. AchilleasTsompanos and TriantafyllosMakarios." Approximate seismic analysis of multi-story buildings with mass and stiffness irregularity", The $5^{\text {th }}$ international conference of Euro Asia civil engineering forum, DOI: 10.1016/j.proeng.2015.11.147.

[6] S. varadharajan, V.K. sehgal and BabitaSaini. "Seismic behavior of multistory RC building frames with vertical set back irregularity" structural design of tall specific building, wiley online library, 23, 1345-1380 (2014) DOI:10.1002/tal.1147.

[7] Devesh P. Soni and Bharat B. Mistry. "qualitative review of seismic response of vertically irregular building frames" ISET journal of earthquake technology, vol.43, issue no.4, December 2006.

[8] GiinayOzmen. KonurlapGirgin and YavuzDargun.”Torsional irregularity in multy-story structures", International Journal of advance structural engineering (2014) 6:121-131. 